\title{
The Power of Selecting Lexicon in the Headline of Printed Media as the Core of Critical Reading Study
}

\author{
Reny Wiyatasari ${ }^{1}$, Suharyo $^{2}$, M. Suryadi ${ }^{3}$

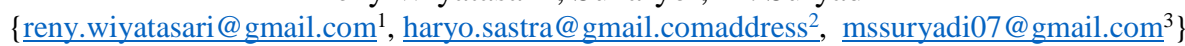

Department of Indonesian Literature, Faculty of Humanities, Diponegoro University, Semarang 50275-

Indonesia ${ }^{1}$, Department of Indonesian Literature, Faculty of Humanities, Diponegoro University, Semarang 50275- Indonesia ${ }^{2}$, Department of Indonesian Literature, Faculty of Humanities, Diponegoro University, Semarang 50275- Indonesia ${ }^{3}$

\begin{abstract}
The purpose of this research is to make the formation of headline form of news of print media which has high accuracy value on the word-concept-referent relationship. Research location in Semarang City. Form of data is the headline text media print media published Semarang City. Selection of respondents and informants using a purposive sampling system on readers. Data collection is done through observation, interview and focus group discus. Data analysis using van Dijk theory: data is placed on the dimensions: context, social cognition, and text. The research findings are designing the syntactic structure of the headline of print media through three basic components: micro structure, super structure, and micro structure. The placement of lingual elements in each component has a unified strength, in the form of (1) repetition of the pronoun, (2) repeating the same lexicon, (3) topicalization of the topic.
\end{abstract}

Keywords: word; concept; referent; headline; print media.

\section{Introduction}

The purpose of this research is to make the formation of headline form of news of print media which has high accuracy value on the word-concept-referent relationship so that the information we have is easy to be understood and have the strength in the linguistic landscape. Simultaneously, these findings can be used as softskills in rhetorical studies. Research location in Semarang City. Form of data is the headline text media print media published Semarang City. Selection of respondents and informants using a purposive sampling system on readers and news peluruh. Case study case study. Data collection is done through observation, interview and focus group discus. Data analysis using van Dijk theory: data is placed on the dimensions: context, social cognition, and text. This placement considers the lingual elements of the component parts: (1) the micro structure, (2) the super structure, and (3) the microstructure. The research findings are designing the syntactic structure of the headline of print media through three basic components: micro structure, super structure, and micro structure. The placement of lingual elements in each component has a unified strength, in the form of (1) repetition of the pronoun, (2) repeating the same lexicon, (3) topicalization of the topic.

Writing the text in newspaper news involves many components, namely as follows. (1) Communicators (journalists/editors), parties who deliver messages/news to the audience. (2) 
Message (text), the content of the news to be delivered. In this component, the point of view of the speaker is crucial in the content of the news that will be delivered (including its alignments). (3) Media, the channels which can be physical: print-circulation. (4) Readers/communicants, individuals and or groups of individuals who are the target of receiving news messages. (5) Gatekeeper/editorial board, the party that has the authority to regulate the regulation of messages/news to be delivered. (6) Company/company, owner of the financing of all printing budget regulations. (7) The reciprocal response between communicators and communicants.

To parse what is stored in the news media in the newspaper, as well as to unravel the messages conveyed and delivered messages to the public, a comprehensive analysis is needed. A comprehensive analysis of the content and strength of messages in the news is critical discourse analysis. Critical discourse analysis as a knife of analysis to understand the nature of lingual use in news media. In this analysis, reviewing news lingual in an integrated manner not separated as in linguistics-, the binding components will be decomposed according to the nature and behavior of the components. The critical discourse analysis used in this study is the theory of Teun A. van Dijk [1] and [2]. Reveals that a text consists of several structures, which each component is supporting each other. Each text built has three levels of structure, as follows. (1) Macro Structure: The macro-structure is a global/general structure, through this structure we can find topics or themes that will be prioritized or focused on in a story. (2) Superstructure: The superstructure is a discourse structure that is related to the text framework, namely how the parts of the text are arranged into a complete story. (3) Microstructure: The Micro-structure is a discourse structure that is related to the micro parts of a text, namely words, groups of words, sentences, clauses, and illustrations.

Van Dijk [3] [4] states that the use and selection of words or sentences in news is part of the journalist's strategy to deliver messages/news. Thus, the selection of words or sentences has been considered as optimal as possible.

The choice of words, sentences, and other linguistic aspects have the following considerations. (1) Selection of micro linguistic elements is seen not merely as a way of communicating. (2) The selection of microelements linguistics is seen as political communication, namely a way to influence public opinion, create support, strengthen legitimacy, and get rid of opponents or opponents. (3) The choice of words in the discourse structure may be chosen to reinforce choices and attitudes, shape political awareness, and so on. (4) The discourse structure is an effective way to see the process of rhetoric and persuasion that carried out when someone delivers a message.

The results of this study become sharper when theory and data analysis utilize the theories and results of previous research as a reference. There are scientific works that are used as references, as follows.

Firth in Widdowson [3] explains that discourse analysis is an attempt to understand the meaning of speech in context, text, and situations. The three components are a part that cannot be separated in the discourse, even though the adhesiveness of each component varies in supporting the discourse message delivered.

Jorgensen \& Phillips [4] explains that critical discourse analysis is an imprecise interdisciplinary study by utilizing other scientific components so that a comprehensive result is obtained. Discourse is part of the empirical world. Besides the content of the text, there is a message loaded with various interests, both implicitly and explicitly. Discourse is a strategic tool/instrument for conveying messages and certain interests, in addition to the contents of the text contained in the syntactic sequence. 


\section{Method}

The location of this study is in the Semarang City. The data collecting is done by referring to the method developed with the Teknik Dasar Sadap and advanced techniques in the form of the Teknik Catat and Teknik Rekam [5]. Data analysis use the descriptive-qualitative method to parse empirically the selection of lexicons in print media headlines. The election that considers the power of information in the upstream syntactic structure. Intangible data collection of words in a syntactic structure is examined through analysis of critical discourse belonging to van Dijk [1]. The involvement of van Dijk's theory in text structure analysis involves three main dimensions, such as: text, social cognition, and context. In order to understand the text, structure of discourse with its elements is needed. Discourse structure: macro-structure, superstructure, and micro-structure. Elements that follow the structure are influenced by the delivery of information with various interests. The selected data will be reduced through cells in the table. Cells used include information-element upstream structures [6].

\section{Results and Discussion}

\subsection{Structure of the Syntax of Headlines for Print Media News}

Syntactic structure in the headline of printed media coverage has the main elements, namely words, groups of words, sentences, semantics, and syntactic structures. This basic element is in the microstructure in a discourse, so that the use and selection of elements is the main consideration.

This critical discourse analysis starts with the study of microstructure. The procedure is applied with the consideration that this study focuses more on the lingual component to build wider construction, namely the message that will be conveyed to the reader, more neutral or certain partial interest involved.

\subsection{Headline}

The microstructure data containing the sentence elements "Buni Yani Bersumpah Tak Potong Video" is composed of six words, each of which contains different lexical meanings. The element that composes as a unit of the lexicon in the sentence structure. Thus, the lexical meaning contained in each lexicon shifts to a higher structure, namely the sentence. The next element will shift is the lexical meaning to be grammatical. The process of change, as follows.

(1) Word $\rightarrow$ lexical meaning
(a) Buni Yani : : the said person's name
(b) Swear : take an oath (grammatical meaning)
(c) did not : : negation
(d) cut : eliminating something (lexical meaning)
(e) video : a noun

(2) Linear words sequence : Buni Yani swore he did not cut the video.
(a) Sentence
: Buni Yani swore he did not cut the video (grammatical meaning)
(b) Sentence
: sentence structure $S$-P-Pel 
This description of each component, which leads to these elements can not stand alone. The lexicon element forms a linear sequence as the intrinsic nature of a language [7]. This linearity forms a larger linguistic element which is a sentence. A sentence is a linguistic unit that conveys complete information/messages. This completeness is characterized by syntactic fill units, namely functions, categories, and roles.

Analysis through this syntactic element shows that the sentence Buni Yani bersumpah tak potong video is a complete syntactic unit. The central element is in the Predicate function, verbal category plays an active role. So that the message delivered is complete namely.

\subsection{Subheadline}

Subheadline in data discourse 1: Ahok Video Plaintiff Sentenced to 1.5 Years in Prison. Used to support the power of linguistic elements that build headlines. The strength of the news media's headlines is reinforced through the repetition of elements. Repeat this element in the form of (1) repetition of pronouns, (2) repeaters of the same lexicon, (3) topicalization of topics.

Repetition of pronouns can be shown in the chart abstraction below. The lexicon of Buni Yani's self-fulfilling headline element is repeated with a lexicon change, namely repetition in the form of an evocative pronoun. The Budi Yani lexicon (headline) and evocator (subheadline) have the same meaning field and the component analysis structure has the same meaning. Thus this discourse building is very strong which is supported by elements in the micro-structure.

The repetition of the same lexicon on the subheadline: video as a video lexicon element on headlines. Repetition is described in the following chart. Repetition of the same lexicon element on subheadline videos as well as the strengthening of the topic on the subheadline, namely video evocator. Thus the function in the syntactic structure occupies the nominal category function

\subsection{Super Structure}

Super Structures in critical discourse analysis related to building discourse schemes, can be text frameworks. The text framework must have strong cohesion and coherence [8]. This power can be shown as a pyramid building.

\section{Conclusions}

Based on the results of the research analysis "The Strength of the Selection of Lexicon in the Headline of Print Media as the Upstream Information of Critical Discourse Study" the power of lexicon selection on print daily headlines is influenced by extra-lingual power, that is, the message is constructed by structures outside the text. (2) the message, (3) media, (4) communicant, (5) gatekeeper, (7) company, and (8) response, and the strength of social cognition that occurs in the community.

Based on the results of the research analysis "The Strength of the Selection of Lexicon in the Headline of Print Media as the Upstream Information of Critical Discourse Study" the power of lexicon selection on print daily headlines is influenced by extra-lingual power, that is, the message is constructed by structures outside the text. (2) the message, (3) media, (4) 
communicant, (5) gatekeeper, (7) company, and (8) response, and the strength of social cognition that occurs in the community.

\section{References}

[1] L. Lihua, "Discourse and Power by Teun A. van Dijk," J. Socioling., vol. 14, no. 2, pp. 283-284, 2010.

[2] C. Meersohn, "Introducción a Teun Van Dijk : Análisis de Discurso," Cinta de Moebio, vol. 24, pp. 288-302, 2005.

[3] H. Widdowson, “J.R. Firth, 1957, Papers in Linguistics 1934-51,” Int. J. Appl. Linguist., vol. 17, pp. 402-413, 2007.

[4] M. Jorgensen and L. J. Phillips, "Discourse Analysis as Theory and Method," Theory, vol. 11, no. 4, p. 229, 2002.

[5] M. Suryadi, "Peran Keluarga Muda Jawa terhadap Penggunaan Bahasa Jawa pada Ranah Keluarga di Lingkungan Perkampungan Kota Semarang," NUSA, vol. 12, no. 2, pp. 14-23, May 2017.

[6] Sudaryanto, Metode dan aneka teknik analisis bahasa: pengantar penelitian wahana kebudayaan secara linguistis. yogyakarta: Duta Wacana University Press, 1993.

[7] Sudaryanto, Pemanfaatan Potensi Bahasa: Kumpulan Karangan sekitar dan tentang Satuan Lingual Bahasa Jawa yang Berdaya Sentuh inderawi. yogyakarta: Kanisius Publishing, 1989.

[8] A. Munandar and A. Munandar, "Analisis Struktur Retorika: Alternatif Pemahaman Koherensi Wacana Selebaran Partai Rakyat Demokratik," Humaniora, vol. 13, no. 2, pp. 150-163, 2012. 